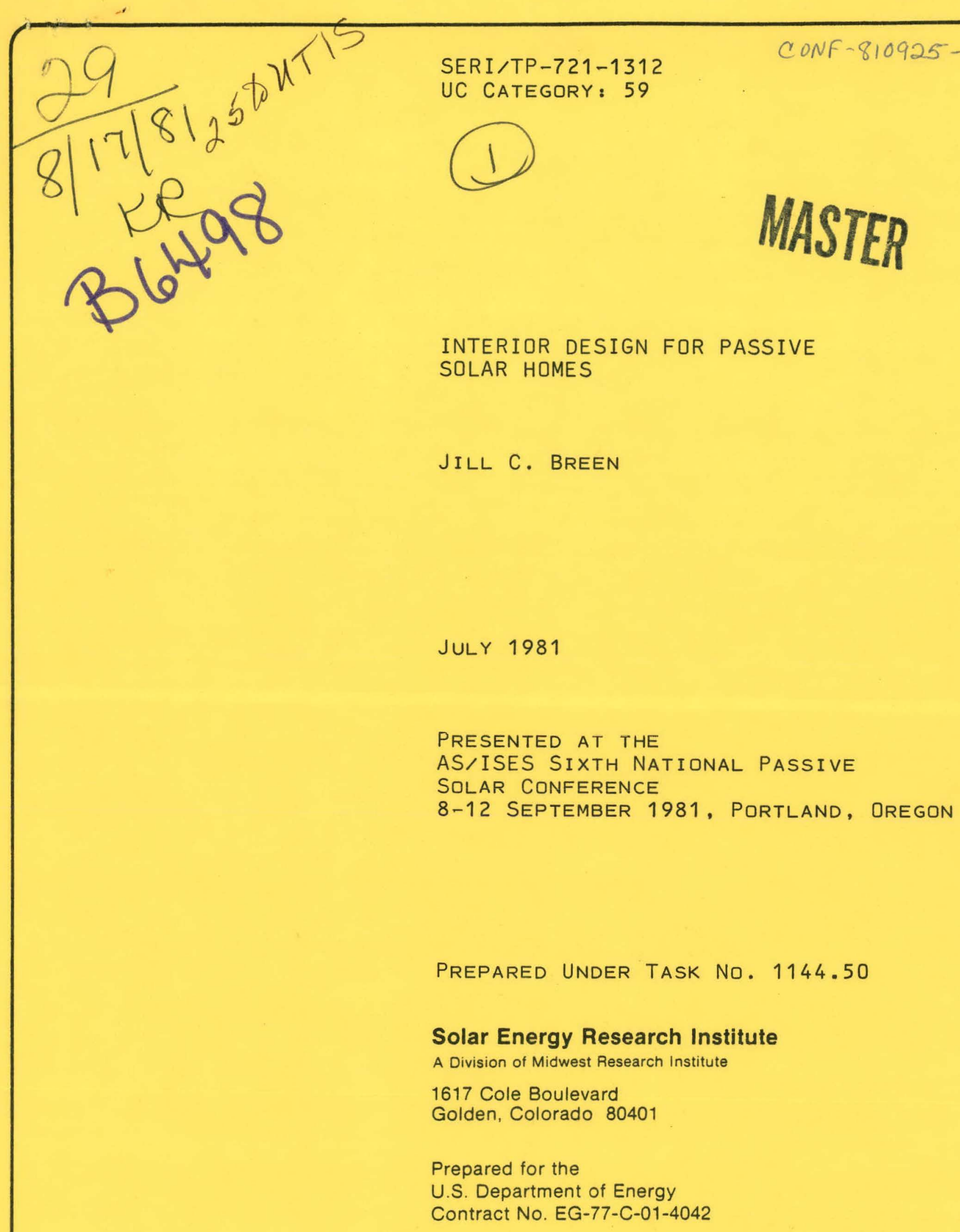




\section{DISCLAIMER}

This report was prepared as an account of work sponsored by an agency of the United States Government. Neither the United States Government nor any agency Thereof, nor any of their employees, makes any warranty, express or implied, or assumes any legal liability or responsibility for the accuracy, completeness, or usefulness of any information, apparatus, product, or process disclosed, or represents that its use would not infringe privately owned rights. Reference herein to any specific commercial product, process, or service by trade name, trademark, manufacturer, or otherwise does not necessarily constitute or imply its endorsement, recommendation, or favoring by the United States Government or any agency thereof. The views and opinions of authors expressed herein do not necessarily state or reflect those of the United States Government or any agency thereof. 


\section{DISCLAIMER}

Portions of this document may be illegible in electronic image products. Images are produced from the best available original document. 
Printed in the United States of America Available from:

National Technical Information Service

U.S. Department of Commerce

5285 Port Royal Road

Springfield, VA 22161

Price:

Microfiche $\$ 3.00$

Printed Copy $\$ 4.00$

\section{NOTICE}

This report was prepared as an account of work sponsored by the United States Government. Neither the United States nor the United States Department of Energy, nor any of their employees, nor any of their contractors, subcontractors, or their employees, makes any warranty, express or implied, or assumes any legal liability or responsibility for the accuracy, completeness or usefulness of any information, apparatus, product or process disclosed, or represents that its use would not infringe privately owned rights. 


\title{
INTBRIOR DESIGN FOR PASSIVE SOLAR HOMES
}

\author{
Jill C. Breen \\ Solar Energy Research Institute \\ 1617 Cole Boulevard \\ Golden, CO 80401
}

\section{ABSTRACT}

The increasing emphasis on refinement of passive solar systems has brought recognition to interior design as an integral part of passive solar architecture. Interior design can be used as a finetuning tool minimizing many of the problems associated with passive solar energy use in residential buildings. In addition, treatment of interior space in solar model homes may be a prime factor in deter mining sales success.

A new style of interior design is evolving in response to changes in building form incorporating passive solar design features. The psychology behind passive solar architecture is reflected in interiors, and selection of interior components increasingly depends on the functional suitability of various interior elements.

\section{PROBLEM SOLVING THROUGH INTERIOR DESIGN}

Interior design is a finishing touch in passive solar architecture. A complementary working relationship between the building design and interior can create a comfortable living environment. Since the averege person spends 75 percent of his or her time indoors (1), a livable house is very important. in each specific building, architecture and interior design should have a common goal; to develop the most thermally efficient, functional, and attractive space possible.

As with any type or style of architecture, a few problems have been recognized. Various techniques are being devised by architects, interior designers, landscapers, and others to alleviate them. The following sections address issues in the thermal, aesthelic, and sonic cnvironments which can be minimized by innovative interior design.

Many of the problematic areas were identified by the Class $C$ Residential Buildings Monitoring Program, (2) focusing on the field collection and analysis of non-instrumented performance data from 335 passive solar homes.

\subsection{Overheating}

Insufficient thermal mass can cause overheating. Mass can be increased by adding or including high mass struetural features or by using high mass furniture. On the initial plan; fireplaces can be positioned so theyare struck by the sun, and enlarged to provide high amounts of thermal mass. Planters, brick veneer on walls or floor, or pavers with a surface covering are a few of the methods by which mass can be increased.

A second possibi'ity is to use high mass furniture in passively heated buildings. This may be more practical for commercial buildings but can be adapted to residences as well. Retrofits and sun-tempered units are two areas where adding mass by selecting high mass pieces or modifying fumiture may be most useful. Denise Guerin (2), Associate Professor of Housing and Interior Design at Miami University of Oxford, Ohio, suggests that pieces with hollow frames, bases, pedestals, legs, or seats can be filled with water, rocks, or phase-change salts. If furniture is used this way, the floor must be able to withstand the additional weight. Residences are generally designed to support 40 $\mathrm{lb} / \mathrm{ft}^{2}\left(193.7 \mathrm{~kg} / \mathrm{m}^{2}\right)$.

\subsection{Tertile Fuding and Detorioration}

Textiles in direct gain spaces are subjected to unusually high amounts of sunlight. High humidity levels may exist in greenhouses or sunspaces. Sunlight resistance, color fastness, and moisture resistance are major factors to consider. All textiles in areas that receive direct or indirect sunlight are susceptible to fading and deterioration, but the rate of degradation varies depending on fiber content, yarn and fabric construction, dye, finish, end use, and maintenance.

Textile manufacturers generally match properties for the most effective combination of characteristics for a particular end use. For best performance it is essential for textiles to be used in the context they were intended; e.g., don't use bedsheets for curtains since they are not sun-resistant.

Care and maintenance of a textile aro important for a long life. Fabrics are weakened and embrittled by grime, dirt, and pollution. Heat and light accellerate the process so risk is increased in pussive solar homos. 
Several materials lend themselves to various applications in passive solar homes. Fibers acceptable for upholstery are acrylic, cotton, leather, vinyl linen, nylon, polyester, and wool. For window treatments use acrylic, glass, nylon, modacrylic and polyester. Fibers best suited for floor coverings are acrylic, nylon, polyester, and natural wool.

Textiles should be tightly woven, strong, have dimensional stability, and a soil resistant finish. Carpets should have mildew resistant backing.

Refer to textile chart included at the close of the paper for suitability of specific fibers.

\subsection{Shading of Thermal Mass}

In homes where a mass floor is used for heat. storage, furniture should be airy and of lightweight construction to keep shading to a minimum. By using furniture on legs the floor is not inhibited in releasing its stored energy. Light colors, matte finishes, and smooth textures can be used to reflect light to a more efficient thermal mass. These characteristics may not only be used in fumiture but on most interior surfaces. They help to diffuse light making lighting levels more constant within the room. Reducing contrast helps eliminate glare and visual discomfort, as well as distributing light over a larger mass area.

Dining rooms are sometimes used to collect heat in direct gain systems. Large tables placed near south facing windows tend to shade mass floors. If glass top tables are used, light passes through. Furniture should be arranged to keep as much space as possible open near south-facing windows. Theoretically, $8 \mathrm{ft}$ of open space is needed nearest the windows, so arrange furniture with this in mind when practical.

Besides shading, another reason to avoid high amounts of direot light striking lightweight furnishings is that heat is released immediately, increasing the probability of overheating in peak hours and insufficient stored energy for evening hours.

\subsection{Interference with Heat Distribution}

Lightweight fumiture minimizes interference with heat gain and release. Mass walls need circulation space to allow heat to radiate. Trombe walls should not have any furniture or accessories blocking radiation. Paintirus, wall wangings, and pictures should not cover large areas of mass walls, but small accessories or decorative items that transmit light can be used. Some walls incorporate shelves of the same material to hold decorative accessories. Other walls in the same room can be emphasized to compensate for the austerity of mass walls not used as focal points. Using Interesting materials and configurations for the mass itself can eliminate the need for wall decorations.

\subsection{Heat Loss Through Windows}

Heat loss through windows occurs by conduction (warm air traveling to cooler air), convection (warm air drawn across cool glass), and infiltration (air leaks). Movable insulation or window treatments should minimize these heat losses.

Convection can be mirimized by using a cornice board, valence, or other device that blocks the convection loop. To avoid local convection, close the bottom and top by fastening the treatment to the wall or fitting it closely to the sill or floor. The bottom seal is most important.

Conduction can be reduced by covering the glass during pariods of heat loss with an insulating material. Leave an air space between the glass and treatment to entrap air, an additional insulator. For solar gain, the insulation should draw completely off the glass during sunny hours.

The first step in cutting infiltration is to have adequate caulking and weatherstripping. Beyond that, the window treatment should extend past the window casing enclosing the entire unit. An airtight material sealed on both sides and the bottom will prevent air leaks.

New, more sophisticated movable insulation is being developed and placed on the market. Innovative designs, more refined manufacturing techniques, and decorative coverings are overcoming the problem of combining function and aesthetics. William Langdon (3) and William Shurcliff (4) outline the possibilities of shutters, shades, and insulated draperies in their books Movable Insulation and Thermal Shutters and Shades, respectively.

Expense continues to be a problem with the more refined types of movable insulation currently op the market. Costs range from $\$ .50-\$ 15.00 / \mathrm{ft}^{2}$ $\left(\$ 5.38-\$ 161.46 / \mathrm{m}^{2}\right)$ with the insulated draperies, home-mades, and crude types at the lower end of the range, and well-constructed, finely crafted shutters at the upper end.

Installation may be difficult for the more complex types and expensive to have installed by a professional. Clerestories and slanted glass are especially difficult to work with. Tracks have been devised to hold the edges of flexible window coverings close to the frame, even on slanted glass. The manual controls of these systems are sometimes difficult to use.

Hinged shutters require the most room to stack back when opened, which should be considered where space is limited.

There is a definite trade off between price, aesthetics, maintenance liability, and ease of operation. Each individual must weigh the costs and benefits of different types according to their needs and resources. 


\subsection{Acoustical Problems}

Although berming and heavy construction help isolate occupants from outdoor noise, acoustical problems can occur in the interior because of the increased amount of glass and hard surfaces. These problems can be minimized by including acoustical tiles or panels in interiors or increasing soft surfaces with furniture, throw rugs, wallhangings, or, if space permits, a series of vertical sound absorbIng baffles suspended from têll cellings.

\subsection{Aestheties of Thermal Mass}

Materials suitable for a thermal mass have some similar properties. They should absorb light and heat and be able to pass heat from the surface to the inside of the material where it can be stored. Heat absorption mostly depends on surface color and texture. The darker the surface color and the more heavily textured the more heat and light absorbed. Any material with these characteristics can be used as thermal mass. Possibilities for creativity and innovation include:

- patterns with various brick bonds;

- irregular shapes and sizes of stone;

- interesting types of rock, such as lichen rock or river rock;

- bricks set in sculptured patterns;

- blue, green, or gray slate over concrete;

- ceramic tiles;

- mosaics;

- frescoes;

- sculptured ceramic walls of fired clay; and

- quarry tile.

\subsection{Privacy}

Because of the increased amount of glass, use interior decorative screens, plants, $\alpha$ hangings as visual shields. Window insulation will alleviate the problem at night. Also, try exterior fences, hedges, or other landscaping. Separate the heat collection area from the living space with an interior visual barrier.

\subsection{Glare}

Glare results from contresting light levels within a space. Reducing glare is important in overall energy efficiency because a $1 \%$ increase in glare requires a $15 \%$ increase in lighting to maintain the same perceived lighting level. The simplest and most effective method of reducing glare is to diffuse the light evenly by using textured or matte surfaces and light colors. Placement of glazing also influences glare. For example, clerestories rather than south-facing windows provide diffused overhead lighting, which is superior to direct sunlight on a work surface or living area.
Window and door heat-gain retardant films can be applied to glazing surfaces to help reduce glare and heat. These films tend to be permanent. They can be removed, but the task is laborious and reapplication can be difficult. For this reason, they should not be used on south-facing windows intended for heat gain. Screens are effective but, since they also reduce solar gain, can only be used in the summer.

\subsection{Traffic Patterns}

Passive design dictates that interior spaces be zoned according to their light and heat requirements. Living rooms, bedrooms, and dining and kitchen areas require the most energy for light and heat and are located on the south sides of most passive buildings. Room locations should consider circulation patterns and traffic flow as well as energy efficiency. Activity areas should follow a natural progression and arranged with equal emphasis on livability and energy efficiency. For example, buffer zones such as bathrooms and utility rooms should be laid out for convenience as well as acting as ther mal barriers.

\section{CASE STUDIES}

Three distinct interior design approaches were demonstrated in the Passive Solar Tour of Homes, the market development stage of the Solar Homebuilders Program partly sponsored by the Solar Energy Research Institute. Two approaches were considered successful in promoting sales and one was believed to have detracted from the home and discouraged buyers. Although many factors such as size, price, location, and style intervened, many people involved with marketing the homes on the tour agree that interiors were a significant factor in determining sales success.

One approach was to leave the interior unfurnished, reasoning that merchandising the home would detract from the simplicity of the solar system. This was quite successful judging from sales. The second case study inappropriately used traditional interior designs in a nonconventional, solar home. This model received a negative response, and sales were poor. The interior designer in the third case was sensitive to the psychology behind passive solar architecture and integrated the interiors with the natural environment, which complemented the simplicity of the solar system. This home experienced the highest number of sales of any house featured on the tour. This unique home sets a precedent for the new style of interior design, which is both thermally efficient and aesthetically pleasing. It intelligently uses many of the interior design problem solving techniques mentioned in this paper.

\section{CONCLUSION}

As fuel prices continue to soar, passive solar energy becomes more and more attractive to home 
buyers. Interior design in passive solar buildings can increase their livability and consumer acceptance. Widespread use of solar energy will come as a result of a comfortable, functional living environment-not from energy-efficient houses that are like test cells. Thoughtful interior design can minimize many of the current problems associated with solar energy use. Exchanging information among interior-designers, solar architects, and builders is needed to improve the quality of life in solar homes.

\section{REPBRENCES}

(1) Mills, Mapolia, Indoor Air Pollution: Recommendations To The Contress, Solar Energy Research Institute, Golden, CO, 1980.
(2) Towle, Sharyn. Class C Residential Buildings Monitoring Program, Solar Energy Research Institute, Golden, CO, (fortheoming).

(3) Guerin, Denise. "Interiar Applications for Passive Solar Design," Nebraska Handbook of Passive Design, University of Nebraska Press, Lincoln, NB, (1980).

(4) Langdon, William $\mathrm{K}$. Movable Insulation, Rodale Press, Emmaus, PA, (1980).

(5) Shurcliff, William A. Thermal Shutters and Shades, Brick House Publishing Co., Inc., Andover, MA, (T980).

(6) Guerin, Denise, "Interior Applications For Passive Solar Design" Nebraska Handbook of Passive Design, University of Nebraska Press, Lincoln, NB, T980. 
Etability of Fibers to Broironmental Conditions (5)

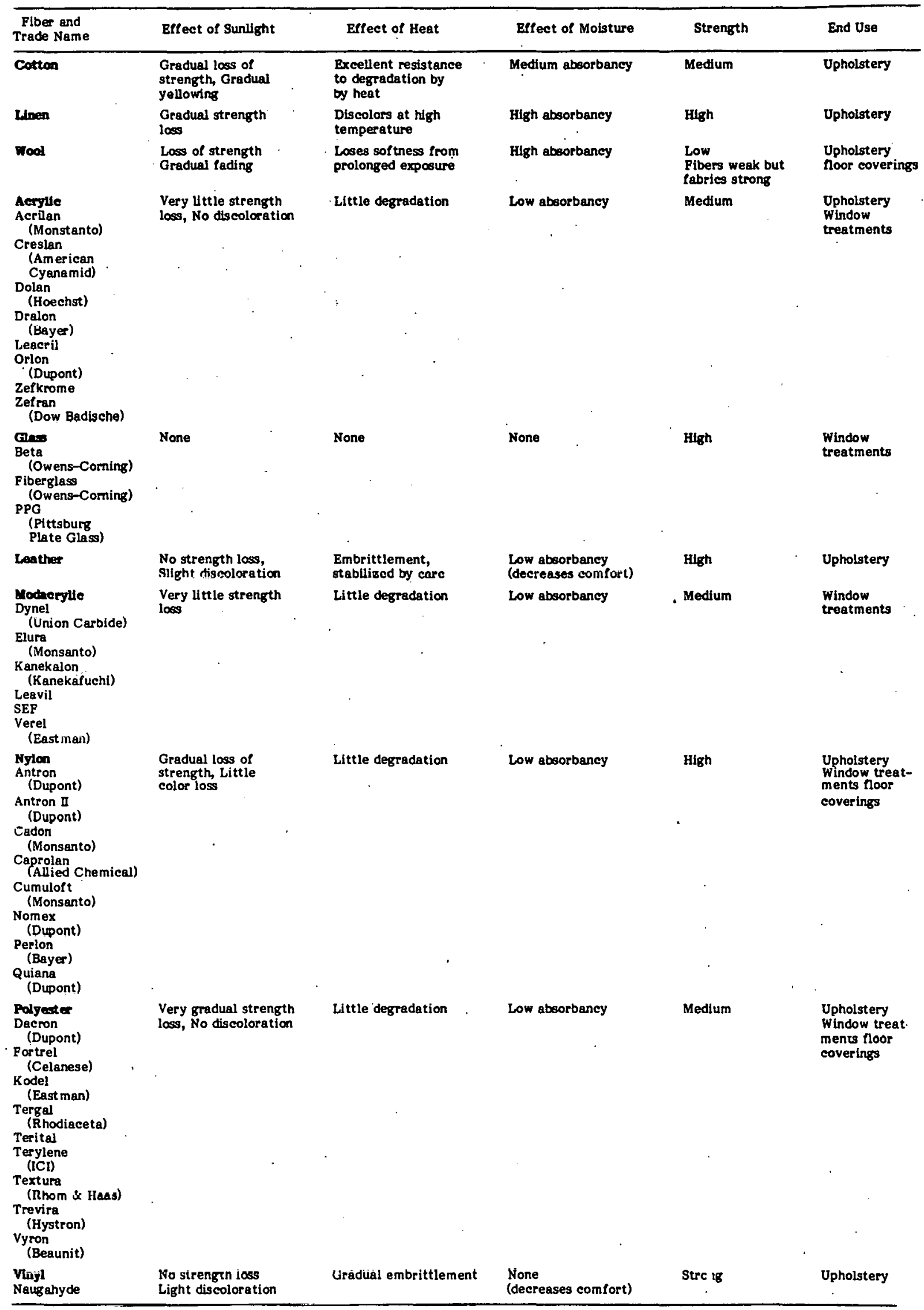

